\title{
J
}

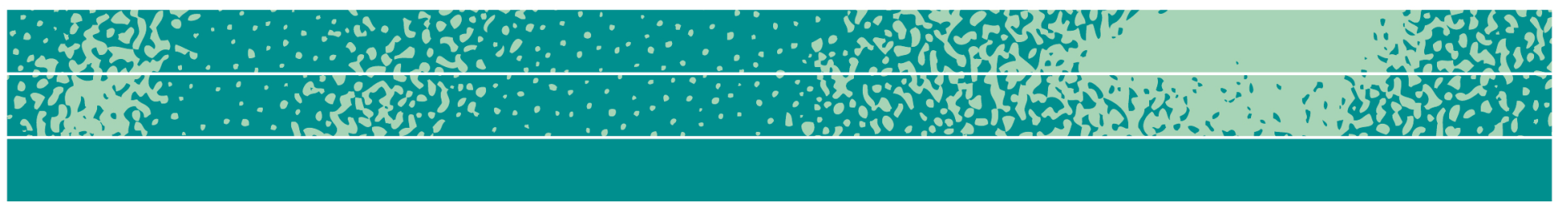

Comment on Salverda:

\section{To Critique or not to Critique? That is (perhaps not) the Question...}

\author{
Hannah Appel
}

How do powerful corporate actors interact with critique? Salverda poses this question in part to encourage anthropologists to be more attentive to the ways that corporate practices shift in response to criticism. Far from fixed materializations of capitalism, corporations can be surprisingly porous and reactive. In place of, or perhaps alongside, "anthropology's ritualized disloyalty to elites" (3) then, Salverda encourages both close ethnographic attention to unfixed corporate practices, and reflexive attention to anthropologists' own interpretive choices, including a disciplinary tendency to critique capitalist enterprises rather than focus on "positive developments" (17).

Corporations respond to their critics. Salverda is in good company in this argument (Benson 2011, Golub 2014, Kirsch 2014, Rajak 2011, Stuesse 2016, Tarbell 1904, Welker 2014 inter alia) Such good company that I find the argument at once unassailable and unremarkable. From strikes to shame campaigns to investigative journalism to boycotts to shareholder activism to occupations and blockades and sabotage to critical scholarship to legal battles to transnational networks of activists and NGOs involved in some and all of these tactics, corporations have
Page 1 of 6

JBA 8(1): 29-34

Spring 2019

(C) The Author(s) 2019

ISSN 2245-4217

www.cbs.dk/jba 
responded to critics at least since the 17 th century, when the Dutch East India Company and later the British East India Company began waging war across Asia in search of wealth, luxury goods to trade for enslaved Africans, and eventually corporate sovereignty over India. If the fact that corporations respond to their critics is unassailable, however, the article also thinks through two more inchoate, intertwined themes: first, the question of interpretive choice (to critique and only critique? To offer an equally robust account of the "positive developments" the corporation may bring?); and second, the question of capitalism itself. How do we understand it? How do we understand a given corporation's relationship to it? What is the relationship between "positive developments"companies raising wages, guaranteeing a measure of environmental protection, or offering Corporate Social Responsibility projects like drinking wells or school buildings - and capitalism more broadly?

As an anthropologist who engages corporations ethnographically (Appel 2012, 2017, 2018, forthcoming 2019) my approach to interpretation and analysis in writing emerges from my interpretation and analysis of capitalism itself. Refusing both totalizing theories that attribute to capitalism an intrinsic systematicity or logic, and arguments for an endlessly varied, specific, and fractured form, my research has traced the work of U.S. oil corporations in Equatorial Guinea, and in so doing, attempts to show the relationship between capitalism's coherence and power and the radically heterogeneous sites through which those qualities are made (see also Bear et al 2015). In place of a focus on corporate scandal, exploitation, or environmental degradation, (or corporate "positive developments" for that matter) I am interested in the licit life of capitalism-contracts and the corporate form, infrastructures, economic theory, "transparency" - that allows oil and gas to move from subsea deposit to futures price with both mundane reliability and spectacular accumulation. In short, ethnographic attention to quotidian corporate practices allows me to watch the making and remaking of capitalism as a project, to attend to its effects without attributing to it an inevitable logic or rationality. In the absence of a stated approach to or interpretation of capitalism, Salverda seems a priori tripped up by the tension between "structural conditions of capitalism" and its specificities in a given project, and perhaps by a synechdocal transposition of a single corporation for capitalism writ large. Ethnographic research and historical context can pose questions through these impasses.

\section{Interpretive Impasse 1:}

Should the anthropologist dismiss a company's attempts to offer better conditions [to Zambians affected by their project] even when the company does not share concerns about, or is not aware of, certain structural limitations addressed in critiques of capitalism? Ethnography 
asks us to answer this question through research: what are the specific "better conditions" on offer? What were the processes through which those conditions were realized, and what have been their effects to date? How did the ostensive beneficiaries participate in those processes and how do they feel about that process and its' outcomes? Have the "positive developments" changed Zambians' material conditions in meaningful and sustainable ways? Specifically, has the corporation internalized its externalities? Rather than swapping dispossession for a drinking well, have they agreed to mitigate environmental destruction for the length of the project and its afterlife? To allow workers to unionize in any company-related labor? To pay any new tax burdens that might affect Zambians with newly titled land? More broadly, what can we learn from ethnographic and historical precedents that trace the effects of the privatization of land? What are the relevant regulations from the Zambian state? Labor laws? Private property laws? Tax laws? Environmental protections? Right to unionize? Or, has the state granted the corporation tax havens and generous contractual terms? Finally, how do today's "better conditions" compare to similar practices that date back at least a century in Zambia? In other words, we can address ideological anxietyhave our corporate interlocutors read Marx? - with empirical and historical work.

What might it yield, for instance, to think through the long history of transnational corporate booms and busts in Zambia? (Ferguson 1999). One could read one of Salverda's descriptions-"on the one side, a corporation with expensive machinery, well-paid managers, and fridges filled with plenty of food and drinks. On the other side there were rural residents living mostly in simple huts with no electricity, and mainly eating from what their land produced"-as a specific kind of temporal seduction. It is tempting here to see Africa's timeless poverty, and Europe's self-actualized modernity; an ahistorical description in which "positive developments" like a brick house might indeed seem like wealth transfer. Perhaps this corporation will finally incorporate poor Zambians into wage labor, or houses with brick walls. But of course transnational corporations have unpredictably incorporated and then ejected Zambians from precisely these conditions across nearly a century. Large scale copper mining began in Zambia in the 1920s (Ferguson 1999). Many Zambians who worked in those mines had also had long-term employment before that in the mines of what were then called the Belgian Congo and Southern Rhodesia. Zambia's place in these transnational economies was vibrant; Zambia Airways was established on the eve of independence in April 1964, and labor unions were strong and organized. The poverty that we see in Salverda's description then, is not simply lack, but loss (Ferguson, 1999). Knowing this history allows us to ask more interesting questions about inequality and the systemic (as in, reliable over historical time) effects of transnational capitalist enterprise. We could ask with Magubane (1969), how did Europeans come to dominate 
Africans? Own African land? Salverda's seductive description is in fact a palimpsest of conquest, colonial rule, and centuries of predatory violence and economic exploitation. Both corporate social responsibility and "development," to which it is closely related are "laid on top of alreadyexisting geopolitical hierarchies" (Ferguson 1999: 248). Only with that fact in mind can we then assess the present company's actions in this much longer history of transnational capitalist relation of which they are a mere and fleeting part.

\section{Interpretive Impasse 2:}

If corporate actors indeed respond to criticism, how should the critic take part in that relationship? Is it enough to hope for, and to aim critique toward, a kinder gentler capitalism of the kind corporations may enact? Or, must critique always be systemic and (most often implicitly) premised on the potential of capitalism's undoing, and thus an intervention that corporations would not enact without agonistic struggle? Here again I think the answer lies in how the critic chooses to understand not only capitalism, but also the availability / absence of alternatives to that project. Salverda gives us a hint of his own understanding: "Maybe capitalism is more like a continuum, ranging from the most severe oppression resulting from the aspiration to accumulate capital, on the one side, to a society with much fairer capital distribution, on the other" (5). In response to this understanding, the job of the critic, he writes, is to push corporate actors toward less severe repression. This is clearly a reformist position: capitalism needs to be reformed; perhaps more heavily regulated toward distribution via taxation. Critical scholarly engagement with corporations can push them in this direction. While this is the clearest position on capitalism Salverda stakes out for himself, he seems anguished to do so, in part because of disciplinary pressure to take the more revolutionary (vs. reformist) approach. One question would then be, what would Salverda like to see come of his scholarship? If he would primarily like his scholarship to affect corporate practice, then certainly he should craft that scholarship in a way that's legible to the corporation. If, however, he wants his scholarship to expand the terrain of imaginative possibility around transnational capitalist practices, then he is not bound by that legibility. And of course it could be both / andproducing one kind of output for scholarly journals, and another for corporate reports.

The heart of the impasse here, I think, is capitalist hegemony and its claim on our imaginations. To say that capitalism is hegemonic is to say that it "is sufficiently secure and flexible in its basic structures that there is no [single] strategy possible that immediately threatens it" (Wright 2010:332). In the face of this hegemony, a kinder gentler capitalism often seems to be all we can strive for, even rendering 
anthropology's (often implicit) Marxism somewhat quaint. This is both hegemony's claim on our imaginations and a latent confrontation with the expanded time horizons between reform and revolution. Thus, when people ask me, wouldn't oil companies that follow environmental laws and desegregate workforces be better? Wouldn't oil companies that respect the sovereignty of African states be better? I answer, of course. Of course I succumb to the partiality of liberal reform projects. But as a scholar and activist committed to the radical economic imagination and its enactment, I succumb warily and partially to liberal reform, not least because deep betrayals of justice-colonialism, slavery, white supremacy-subtend the liberal orders to which they refer. We might also commit ourselves warily to liberal reforms because liberalism is felicitous in a liberal world. It allows legible victories like changing laws and holding corporations accountable. And yet, at the same time, if we so choose, we can commit to the fullness and more distant horizons of radical projects. As Combahee River Collective member Barbara Smith put it in talking about the possibilities of social justice for Black women in particular under capitalism, "The assaults from the present system necessitate that most activists work for reforms, but those of us who are radicals understand that it is possible to do so at the very same time that we work for fundamental change-a revolution" (quoted in Kelley 2003:156). Salverda, it seems, is muddling through his own relationship to reform, revolution, and the economic imagination.

\section{References}

Appel, Hannah (2012). "Offshore Work: Oil and the Making of Modularity in Equatorial Guinea." American Ethnologist 39:4. 692-709. https://doi.org/10.1111/j.1548-1425.2012.01389.x

Appel, Hannah (2017). "Toward an Ethnography of the National Economy. Cultural Anthropology 32:2. 294-322. https://doi.org/10.14506/ca32.2.09

Appel, Hannah (2018). Race Makes Markets: Subcontracting in the Transnational Oil Industry. SSRC Items Online Publication. https://items.ssrc.org/race-capitalism/

Appel, Hannah (2019). forthcoming. The Licit Life of Capitalism: U.S. Oil in Equatorial Guinea. Durham: Duke University Press.

Bear, Laura, Karen Ho, Anna Lowenhaupt Tsing, and Sylvia Yanagisako (2015). "Gens: A Feminist Manifesto for the Study of Capitalism."

Theorizing the Contemporary, Fieldsights, March 30. https://culanth.org/fieldsights/gens-a-feminist-manifesto-for-the-studyof-capitalism 
Benson, Peter (2011). Tobacco Capitalism: Growers, Migrant Workers, and the Changing Face of a Global Industry. Princeton: Princeton University Press.

Ferguson, James (1999). Expectations of Modernity: Myths and Meanings of Urban Life on the Zambian Copperbelt. Berkeley: University of California Press.

Golub, Alex (2014). Leviathans at the Gold Mine: Creating Indigenous and Corporate Actors in Papua New Guinea. Durham: Duke University Press.

Kelley, Robin D.G. (2003). Freedom Dreams: The Black Radical Imagination. New York: Beacon Press.

Kirsch, Stuart (2014). Mining Capitalism: The Relationship between Corporations and their Critics. Berkeley: University of California Press.

Magubane, Bernard (1969). The Ties that Bind: African-American Consciousness of Africa. Trenton: Africa World Press.

Rajak, Dinah (2011). In Good Company: An Anatomy of Corporate Social Responsibility. Palo Alto: Stanford University Press.

Stuesse, Angela (2016). Scratching Out a Living: Latinos, Race and Work in the Deep South. Berkeley: University of California Press.

Tarbell, Ida (1904). The History of the Standard Oil Company. New York: McClure, Phillips and Co.

Welker, Marina (2014). Enacting the Corporation: An American Mining Firm in Post-Authoritarian Indonesia. Berkeley: University of California Press.

Wright, Eric Olin (2010). Envisioning Real Utopias. New York: Verso.

Hannah Appel, Ph.D. is an Assistant Professor of Anthropology at UCLA. Her first book - Oil and the Licit Life of Capitalism in Equatorial Guinea (forthcoming with Duke UP, 2019) - is both an account of a specific capitalist project-US oil companies working off the shores of Equatorial Guinea-and an exploration of more general forms and processes-the offshore, contracts, infrastructures, "the" economythat facilitate diverse capitalist projects around the world. These forms and processes constitute the licit life of capitalism, and they take shape within the raced and gendered histories of colonialism, empire, and white supremacy out of which capitalism emerged. Hannah is at work on a second long-term ethnographic project on African owned and capitalized Pan African Banks, and is also a founding member and organizer of The Debt Collective (debtcollective.org). The Debt Collective works to build debtors unions through an emancipatory activation of household debt under finance capitalism: What if mass indebtedness is not simply a liability, but also a potential collective asset or leverage point in the fight to enact the new and radical economic forms we need? 